\title{
Konsep Alkitab tentang Peran Roh Kudus dalam Penginjilan
}

\section{Ruat Diana}

Sekolah Tinggi Teologi Simpson Ungaran

Email: rdianadarmawan@gmail.com

\section{Ayu Rotama Silitonga}

Sekolah Tinggi Teologi Simpson Ungaran

Email: ayurotama@gmail.com

\begin{abstract}
Abstrak: Pelayanan merupakan suatu kewajiban bagi setiap orang yang percaya, termasuk pelayanan penginjilan. Dalam pelayanan, orang percaya tidak bekerja sendiri, melainkan dengan bantuan dari Kuasa Roh Kudus. Alkitab menjelaskan bahwa Roh Kudus memberikan kuasa bagi setiap orang untuk memberikan kesaksian di seluruh muka bumi. Gambaran permasalahan dalam penulisan ini ialah bagaimana konsep Alkitab tentang peran Roh Kudus dalam pelayanan penginjilan? Tujuan penelitian ini adalah untuk memaparkan konsep Alkitab tentang peran Roh Kudus dalam penginjilan.

Adapun metode yang digunakan penulis adalah dengan melakukan studi literature melalui sumber buku dan jurnal-jurnal teologi yang disatukan menjadi sebuah uraian yang baik. . Hasil dan simpulan dari penulisan ini ialah Alkitab menegaskan bahwa Roh Kudus berperan penting dalam pelayanan penginjilan, dalam memberikan kuasa atas orang percaya. Ada tiga cara yang dipakai Allah dalam pelayanan Roh Kudus khususnya penginjilan dalam Alkitab. Pertama, Allah menggunakan aktivitas Roh Kudus melalui firman-Nya atau Alkitab. Kedua, Allah menggunakan pelayanan Roh Kudus melalui kesaksian orang-orang percaya. Ketiga, Allah juga secara langsung menggunakan pekerjaan Roh Kudus dalam kehidupan orang-orang percaya supaya mereka bertobat dan menerima Kristus.
\end{abstract}

\section{Kata Kunci: Peran Roh Kudus, Penginjilan}

\begin{abstract}
Service is an obligation for every believer, including the ministry of evangelism. In ministry, believers do not work alone, but with the help of the power of the Holy Spirit. The Bible explains that the Holy Spirit gives power to everyone to bear witness in all parts of the earth. The formulation of the problem in this paper is what is the biblical concept of the role of the Holy Spirit in the ministry of evangelism? The method used by the author is to conduct literature studies through book and journal sources which are put together into a good description. The author also conducts theological research and Christian education. The result and conclusion of this writing is that the Bible confirms that the Holy Spirit plays an important role in the ministry of evangelism, in giving power to believers. There are three ways that God uses in the ministry of the Holy Spirit, especially evangelism in the Bible. First, God uses the activity of the Holy Spirit through His Word or the Bible. Second, God uses the ministry of the Holy Spirit through the testimony of believers. Third, God also directly uses the work of the Holy Spirit in the lives of believers so that they repent and accept Christ.
\end{abstract}

Key Words: The Role of the Holy Spirit, Evangelism

Article History

Submit:

Revised:

Published:

February $19^{\text {th }}, 2021$

June $11^{\text {st }}, 2021$

Juni $29^{\text {th }}, 2021$ 


\section{Pendahuluan}

Kegiatan pemberitaan Injil merupakan salah satu warna kekristenan. Wijaya dan Darmawan (2016) menjelaskan bahwa penginjilan berasal dari kata Yunani, euangelion yang diartikan sebagai kabar baik. GP (2012) menjelaskan bahwa misi dan penginjilan memiliki hubungan erat, yang mana misiologi menjadi induk dari ilmu misi sehingga dalam penginjilan dapat ditemukan misi (pengutusan). Alkitab menunjukkan bahwa gerakan misi telah dimulai oleh Allah dengan mengutus Yesus menjadi Juruselamat manusia. Gerakan itu dilakukan pula oleh Yesus dengan memilih beberapa orang murid kemudian mengutus mereka untuk mewartakan anugerah Allah. Setiap utusan memberitakan anugerah Allah yaitu Kristus menebus manusia dari dosa sehingga setiap orang yang percaya kepada-Nya diselamatkan (Dever, 2010). Widjaja dan Boiliu (2019) mengungkapkan bahwa tidak hanya Matius 28:18-20 yang menjadi dasar yang menekankan pada Amanat Agung yang di dalamnya termasuk juga pemberitaan Injil. Teks Markus 16:14-28, Lukas 24:46-49; Yohanes 20:21-23, dan Kisah Para Rasul 1:8 menunjukkan bahwa Kristus memandatkan pada para murid untuk melakukan penginjilan. Dari hal ini tampak bahwa gerakan pekabaran Injil oleh para murid dan orang percaya penting untuk dilakukan. Gerakan penginjilan kemudian terus mewarnai pelayanan para rasul sehingga Injil terus tersebar ke berbagai belahan dunia (Rafflesia, 2019). Pelayanan penginjilan memang sudah dilakukan, dan untuk menjangkau jiwa-jiwa untuk bertobat, diserahkan sepenuhnya kepada Tuhan.

Gerakan penginjilan juga terus terjadi hingga di era modern. Objantoro (Objantoro, 2017) menjelaskan bahwa gerakan penginjilan menjadi warna kaum injili di suluruh dunia. Gerakan kaum injili tampak dalam semangat pemberitaan Injil. Di tengah perubahan zaman, gerakan penginjilan terus dilakukan dengan berbagai inovasi sehingga memungkinkan semakin banyak orang yang mendengar kabar baik dan diselamatkan.Diana (Diana, 2019) Berbagai kajian telah dilakukan untuk memungkinkan Injil dapat dipahami oleh penerima berita. Penelitian Siswanto (2017), Herwinasastra (2019), maupun Mawikere (2018) menunjukkan jika upaya kontekstualisasi dilakukan agar Injil dapat dipahami. Demikian pula penelitian yang bersifat teologis dilakukan untuk memperkaya wawasan pelayanan penginjilan. Beberapa penelitian atau pun kajian terdahulu meneliti teks Perjanjian Baru lebih banyak memberi tekanan pada aspek strategi atau praktis dalam misi maupun penginjilan. Misalnya kajian dari Nikolaus, Andi, dan Harming (2020) yang mengkaji perumpamaan penabur benih sebagai pendekatan misi lintas budaya. Kemudian kajian Harming dan Katarina (2019) yang mengkonstruksi strategi pelayanan lintas budaya berdasarkan Markus 4:1-34. Demikian pula kajian yang dilakukan oleh Harming, Imanuel, dan Darmanto (2020) yang mengkaji pelayanan lintas budaya Rasul Paulus dalam Kisah Para Rasul 16:13-40. Penelitian terhadap 1 Korintus 9:19-23 yang dikonstruksi sebagai strategi misi lintas budaya oleh Andi et al (2020) juga merupakan aspek praktis bagi kegiatan misi. Demikian pula penelitian Harefa (2020) memberi tekanan praksis konsep inkarnasi Yesus menjadi model penginjilan multikultural. Sementara kajian yang memberi tekanan aspek teologis bagi misi 
dari Perjanjian Baru adalah kajian Huwae (2020) yang meneliti tentang prinsip dasar pemberitaan Injil menurut Kisah Para Rasul 28:23-31. Demikian pula kajian Ijen dan Polyongkico (2020) yang menganalisis pelayanan Filipus sebagai sebuah konsep teologi kontekstual berdasarkan Kisah Para Rasul 8:4-25.

Dari beberapa penelitian terdahulu tersebut, dalam kajian ini penulis memberi tekanan pada konsep Alkitab tentang peran Roh Kudus dalam penginjilan. Kuasa Rohani dalam penginjilan ini sangat penting bagi orang percaya, karena orang percaya diutus menjadi menjadi garam dan terang di tengah masyarakat. Tanpa kuasa rohani, orang percaya akan mengalami kesulitan dalam melaksanakan tugas pemberitaan kabar baik. Seperti yang dikatakan oleh Packer bahwa Kristus melalui kuasa Roh-Nya memampukan hamba-hambaNya untuk menerapkan dan menjelaskan Injil dengan benar.(Rafflesia, 2019)

Yesus Kristus mengatakan pesan khusus bagi yang percaya sebagai dasar yaitu Amanat Agung Tuhan Yesus, bahwa orang percaya harus menjadikan segala bangsa murid Kristus dan dengan penyertaan kuasa Allah sampai kepada akhir zaman (Mat. 28:18-20). Dari amanat agung tersebut, orang percaya harus menjangkau dunia bagi Kristus. Dunia dapat dijangkau kalau orang percaya pergi dan gereja tidakan dapat menjangkau dunia sekelilingnya kalau gereja tetap tinggal dengan nyaman dalam kelompoknya sendiri. Kemudian setiap orang percaya membimbing orang-orang kepada Dia dan menolong mereka menjadi pengikut-Nya. Lalu komitmen mereka yang sudah mengambil keputusan untuk mengikut Kristus dinyatakan melalui pengakuan iman di muka umum melalui pembaptisan. Serta mengajar orang percaya baru untuk melakukan segala sesuatu yang telah diperintahkan Allah. Tuhan Yesus berjanji bahwa ia akan menyediakan apa pun yang diperlukan umat untuk melaksanakan perintah. Dalam hal ini, ada kuasa rohani yang kemudian menyertai tugas misi tersebut.(Darmawan, 2019; GP, 2012; Henry, 2008).

Allah telah memberikan setiap orang Kristen segala yang diperlukan untuk melayani dan bersaksi tentang Kristus. Karunia rohani adalah pemberian Allah untuk orang percaya dapat melayani, memberitakan Injil dan membangun tubuh Kristus (Ef. 4:12). Tetapi ada pribadi ketiga dari Allah Tritunggal yang menjadi bagian penting dalam misi. Karunia rohani dan berbagai perlengkapan melayani lainnya diberikan oleh Roh kudus (Robinson, 2004). Kuasa Roh kudus sudah dicurahkan kepada pada orang percaya diabad pertama agar mereka dapat bersaksi. Para rasul dan orang percaya pada masa gereja mula-mula diberi kuasa ketika Roh Kudus turun keatas mereka dan mereka kemudian menjadi saksi Kristus di Yerusalem dan di seluruh Yudea dan Samaria dan sampai keujung bumi (Kis. 1:8). Kuasa Roh kudus diberikan supaya orang percaya bekerja sama dengan-Nya bukan untuk mencapai tujuan manusia, tetapi untuk membawa orang-orang kepada Tuhan Yesus (Robinson, 2004). Roh Kudus memperlengkapi para saksi supaya mereka dapat menceritakan Yesus Kristus kepada orang lain. Tanpa kuat kuasa Roh Kudus, pengabaran Injil akan bayang-bayang perasaan takut yang mematikan. Roh Kuduslah yang yang menghidupakan, mengalirkan kuasa kepada setiap orang Kristen yang bergantung pada-Nya sehingga dapat bersaksi. Roh Kudus bekerja 
ketika orang percaya bersaksi dan yang perlu di lakukan orang percaya adalah tunduk kepada Roh kudus.

Berdasarkan latar belakang di atas, maka dikemukakan rumusan masalah kajian ini adalah bagaimana konsep Alkitab tentang peran Roh Kudus dalam penginjilan? Kemudian, tujuan dari penelitian inil adalah tujuan penelitian penelitian untuk memaparkan konsep Alkitab tentang peran Roh Kudus dalam penginjilan.

\section{Metode}

Metode yang di gunakan penelitian kepustakaan. Penulis melakukan studi terhadap berbagai literatur yang memberikan gambaran konsep Alkitab tentang kuasa rohani dalam penginjilan. Beberapa sumber pustaka dari buku dan jurnal dielaborasi menjadi sebuah uraian deskriptif tematis sehingga gambaran konseptual dari penelitian ini dapat disajikan dengan baik. Hasil analisis beberapa sumber pustaka diolah dalam kalimat-kalimat konseptual sesuai dengan tema yang dibangun sebelumnya. Langkah-langkah yang di lakukan adalah melakukan analisis literatur dan buku-buku yang berkaitan dengan penelitian ini, sebagaimana gagasan Smith (2016) tentang penelitian teologi, Zaluchu (2020, 2021) tentang penelitian keagamaan, serta Darmawan dan Asriningsari (2018) yang memaparkan prinsip penulisan artikel ilmiah dalam bidang teologi dan pendidikan Kristen..

\section{Hasil dan pembahasan}

\section{Karya Roh Kudus dalam Penginjilan}

Kelahiran baru adalah karya Roh Kudus. Orang yang percaya dilahirkan baru oleh Roh Allah (Yoh. 3:3-5). Orang percaya itu kemudian menerima Roh Kudus pada saat ia menerima Tuhan Yesus.(Robinson, 2004; Setiawan, 2019). Dalam Roma 8:9 diungkapkan bahwa “... tetapi jika orang tidak memiliki Roh Kristus, ia bukan milik Kristus." Dalam kegiatan penginjilan, tidak ada orang yang dapat menerima keselamatan dalam Kristus tanpa kuasa Roh Kudus. Roh Kudus bekerja dalam hidup setiap orang untuk memanggil mereka mengakui dosa dan hidup berkemenangan di dalam Kristus.(Robinson, 2004). Sebab Roh Kudus adalah pribadi yang bekerja sebagai pemberita yang ilahi.(Fernando, 2000). Penginjil sebagai pemberita yang insani bekerjasama dengan Roh Kudus yang adalah pemberita yang ilahi. Roh Kudus memberi kesaksian kepada orang yang taat dan ikut memberikan kesaksian tentang Injil.(Tong, 1995). Roh Kudus memberikan kekuatan dengan kuasaNya dalam setiap batin orang percaya. Kuasa Roh Kudus bukan hanya dalam hal memberikan kemenangan, melainkan juga dalam hal: Kristus mendiami orang percaya, orang percaya beralas dan berakar dalam kasih, dan orang percaya bersama-sama memahami betapa lebarnya dan panjangnya dan tingginya dan dalamnya kasih Kristus (Ef. 3:16).(Brill, 2003). Dapat dipahami bahwa Roh Kudus pasti bekerja bagi orang percaya yang taat dan sadar akan kasih Karunia Allah dalam memberitakan Injil Tuhan. 
Karya Roh Kudus dalam penginjilan adalah baptisan Roh. Setiap orang dibaptis Roh Kudus saat ia bertobat dan menerima Tuhan Yesus menjadi Juruselamatnya. Dalam 1 Korintus 12:13 diungkapkan bahwa "Sebab dalam satu Roh kita semua, baik orang Yahudi, maupun orang Yunani, baik budak, maupun orang merdeka, telah dibaptis menjadikan satu tubuh dan kita semua diberikan minum dari satu Roh." Baptisan yang dilakukan menggunakan media air melambangkan cara orang tersebut bertobat oleh Roh Kudus, masuk kedalam persekutuan yang hidup dalam Kristus. Seluruh orang percaya sudah menjadi satu Roh.(Guthrie, 2007). Melaui baptisan Roh, orang-orang percaya dipersatukan kedalam tubuh Kristus oleh Roh Kudus. Mereka sudah mengalami pemulihan hubungan dengan Tuhan Yesus dan dipersatukan dengan orang-orang percaya yang lain. Orang-orang percaya menjadi satu tubuh walaupun banyak anggota, karena memiliki satu dasar hidup. Semua orang percaya dihidupkan dan digerakkan oleh Roh yang sama, yaitu Roh Kudus.(Henry, 2015). Baptisan Roh Kudus tidak lain adalah menyambut satu pribadi yang hidup, yaitu Roh Kudus sendiri. Orang yang percaya wajib menerima Dia sama seperti menerima Tuhan Yesus Kristus.(Brill, 2003). Dari pernyataan di atas jelaslah bahwa Roh Kudus pun bekerja untuk mempersatukan orang-orang percaya yang ada di muka bumi ini dalam satu tubuh Kristus.

Meterai Roh Kudus ada dalam setiap kehidupan orang percaya. Pada era Perjanjian Lama maupun Perjanjian Baru, seorang Raja menggunakan cincin materai untuk memberikan tanda resmi pada sebuah dokumen. Dalam konteks penginjilan, Roh Kudus adalah tanda Allah bahwa orang yang percaya sudah menjadi bagian dalam keluarga Allah (Rm. 8:15). Kata "materai" digunakan untuk menyebutkan sebuah jaminan. Dipenuhi oleh Roh Kudus merupakan jaminan bahwa orang percaya sudah ditebus. Allah menempatkan Roh Kudus kedalam hidup orang percaya sebagai jaminan bahwa Dia akan membawa orang percaya kepada tujuan yang dijanjikan-Nya. Orang percaya yang telah dipenuhi Roh Kudus kemudian dipimpin untuk hidup taat pada Allah dan meninggalkan kehidupan.(Robinson, 2004). Pemerteraian Roh Kudus memiliki beberapa kebenaran penting bagi kehidupan orang percaya. Pertama, pemeteraian menandakan orang percaya adalah milik Allah. Kedua, menunjukkan Sekuritas yang berarti bersifat permanen. Ketiga, menunjukkan otoritas Allah akan orang yang akan diberikan Roh Kudus.(Enns, 2003). Dalam hal ini pemeteraian dilakukan Roh Kudus sebagai tanda khusus bagi setiap orang percaya, dan menunjukkan keMahakuasaan Allah dalam memilih umat-Nya.

Setiap orang percaya dihuni oleh Roh Kudus agar dengan tubuhnya orang percaya memuliakan Allah. Setelah menerima Kristus sebagai Tuhan dan Juruselamat pribadinya, orang percaya kemudian dipenuhi oleh Roh Kudus (1 Kor. 6:19-20). Roh kudus hidup dalam diri setiap orang percaya untuk mendatangkan kemuliaan bagi Allah (Sumiwi, 2018). Roh Kudus diberikan kepada orang percaya bukan sebagai imbalan, melainkan karunia yang diberikan sebagai tanda penerimaan akan Yesus Kristus sebagai Juruslamat.

Pemberitaan Injil pada dasarnya adalah pelayanan dari Roh Kudus sendiri yang memberikan penghiburan dan tantangan bagi setiap orang percaya. Suatu penghiburan yang 
berarti Roh Kudus membuat orang percaya sepenuhnya kepada Dia untuk menyelesaikan karya-Nya, dan suatu tantangan yang berarti hanya orang yang dipenuhi Roh, alat yang dikuduskan oleh Roh dan cara-cara yang diakui Roh, yang dapat digunakan secara efektif dalam pelayanan-pelayanan misi.(Wagner, 2006). Dengan demikian, setiap pelayanan yang dilakukan oleh orang percaya akan berjalan dengan baik, ketika Roh Kudus turut bekerja atasnya.

\section{Cara Roh Kudus Membawa Orang-Orang Kepada Kristus}

Allah mengunakan tiga hal dalam pekerjaan Roh Kudus untuk membawa orang-orang kepadanya. Pertama, Roh Kudus bekerja melalui Alkitab. Alkitab menjadi hal penting untuk membawa orang kepada Kristus, karena Alkitab yang merupakan firman Allah adalah Kristus sendiri. Alkitab menjadi sebuah dasar kehidupan dan kebenaran bagi setiap orang. Roh kudus menggunakan Alkitab yang merupakan firman Allah yang hidup, sebagai pedang atau alat membawa orang-orang kepada Kristus (Ef. 6:17; Rm. 1:16). (Darmawan \& Objantoro, 2020; Katarina \& Darmawan, 2019). Roh dan kebenaran diungkapkan dalam Perjanjian Baru yang menggambarkan sebagai agen pewahyuan dan menunjukkan akan pengajaranNya tentang kebenaran. (Fernando, 2000). Dalam hal ini, Roh Kudus menggunakan Alkitab atau kebenaran itu sendiri untuk memberikan pengajaran yang benar, menyadarkan, dan membawa orang-orang yang belum percaya datang kepada Kristus.

Pelayanan yang berkualitas dapat dilihat dari kualitas pemberitaan firman Tuhan, kualitas pelayanan yang menghasilkan kesatuan tubuh Kristus, dan pelayanan yang mampu bertahan dalam segala tantangan.(Soesilo, 2011). Pertobatan melalui firman Tuhan yang didengar merupakan pertobatan yang sejati karena Injil merupakan kekuatan Allah yang mampu menyelamatkan. firman Tuhan atau Alkitab mampu menyadarkan manusia tentang dosa yang membawa kematian, dan mampu menyadarkan diri akan kebutuhan seorang Juruselamat dalam hidupnya.(Sitanggang, 2020). Alkitab bukan hanya mampu mengubah sebuah kehidupan, melainkan juga seluruh gaya hidup seseorang.(Swindoll, 2012). Dengan demikian, Alkitab berperan penting dalam penginjilan dan Roh Kudus menjadikan Alkitab sebagai dasar untuk menolong seseorang mengalami suatu perubahan yang baik dalam dirinya.

Kedua, Bekerja melalui orang-orang Percaya. Roh kudus bekerja melalui saksi-saksi Kristus untuk membawa orang-orang kepada Tuhan Yesus. Tuhan memakai orang-orang untuk menjangkau orang-orang lain. Roh kudus bekerja melalui kepribadian orang Kristen untuk menjangkau dan menjamin mereka yang yang memerlukan Kristus. Dalam Perjanjian Baru, Roh Kudus memakai para rasul dalam pelayanan. Roh Kudus melengkapi para rasul dengan Kuasa-Nya (Kis.1:8). Kepenuhan Roh Kudus, menjadikan para rasul berani dan berhikmat dalam melayani dan pemberitaan firman Tuhan.(Lumintang, 2006). Dalam hal ini, Roh Kudus yang akan memimpin dan membimbing orang percaya untuk melakukan pelayanan atau penginjilan. Roh Kudus berperan seperti pemandu atau pemimpin jalan.(Enns, 
2003). Dapat dimengerti bahwa Roh Kudus sudah ada dalam diri setiap orang yang percaya kepada-Nya. Oleh sebab itu, Roh Kudus tidak hanya memakai Pelayan Tuhan secara khusus, tetapi Roh Kudus mampu memakai orang percaya untuk menjadi alat-Nya dalam menyampaikan firman Tuhan.

Melalui kehidupan yang benar, orang percaya bisa menjadikan kehidupannya menjadi saksi bagi orang yang belum percaya, dengan pertolongan dari Roh Kudus. Penginjilan atau pemberitaan firman Tuhan harus merupakan sesuatu yang mengalir dari kehidupan orang percaya.(GP, 2012). Roh Kudus memperlengkapi para saksi untuk menceritakan Yesus Kristus kepada orang yang belum percaya. Roh lah yang akan menghidupkan orang percaya dalam penyampaian firman Tuhan, dan menghilangkan perasaan takut. Kuasa Roh Kudus akan bekerja dengan sendirinya dalam kesaksian orang percaya.(Robinson, 2004). Roh Kudus menerangi dan menolong orang yang sedang diinjili, untuk membuka hati dan mengundang Yesus Kristus masuk dalam kehidupannya secara pribadi.(Tamarol, 2020). Roh Kudus memimpin orang percaya dalam pewahyuan yang tiba-tiba timbul dalam dirinya. Pewahyuan itu bisa berlangsung beberapa menit untuk disampaikan kepada orang lain, tetapi pewahyuan itu bisa datang melalui Roh Kudus dalam waktu beberapa detik saja.(Servant, 2004). Dalam hal ini, Roh Kudus akan bekerja untuk memimpin orang percaya dalam pelayanan. Dorongan Roh Kudus besar dan mutlak, sehingga orang percaya tidak akan berhenti memberikan kesaksian yang berarti.(Dixon, 2005). Dari setiap pernyataan di atas dapat dipahami bahwa Roh Kudus sangat berperan dan berkuasa atas pewahyuan atau pemberitaan firman Tuhan kepada setiap orang yang belum percaya. Melalui anak-anak Tuhan yang melayani, Roh Kudus memberikan kuasa-Nya kepada orang percaya untuk memberanikan diri bersaksi melalui hidup bersama Tuhan dan bersaksi tentang Injil Tuhan. Orang percaya tidak melayani dengan kekuatan sendiri, melainkan dengan kekuatan dan kuasa Roh Kudus.

Ketiga, Membawa orang-orang yang belum percaya kepada Kristus. Roh Kudus bekerja dalam kehidupan orang-orang untuk membawa mereka kepada Kristus. Melalui kesaksian seorang percaya firman Allah telah dibagikan kepada orang yang belum percaya, tetapi melaui firman Tuhan, Roh kudus menembus hati, pikiran, dan jiwa orang yang belum percaya. Roh Kudus menunjukkan karya-karya-Nya yang serupa dengan karya-karya dari Allah Bapa dan Putra. Salah satunya ialah Roh Kudus meyakinkan, yang berarti meyakinkan seseorang akan sesuatu dan menunjukkan sesuatu pada seseorang. Roh Kudus bekerja dengan Kuasa-Nya untuk meyakinkan dosa, kebenaran dan penghakiman.(Enns, 2003). Dalam hal ini, Roh Kudus akan bekerja untuk meyakinkan hati orang yang mendengarkan berita firman Tuhan yang sudah disampaikan dan menjadikannya percaya. Yohanes 16: 8-11, mengatakan bahwa Roh Kudus yang datang akan menginsafkan manusia dari dosa dan penghakiman. Roh Kudus berkuasa atas pelayanan yang memungkinkan orang belum percaya dimenangkan bagi Kristus. Orang yang belum percaya dapat dimenangkan bila sesuai dengan kehendak Allah dan pimpinan Roh Kudus.(Miranda, 1986). Pelayan Tuhan atau orang percaya bertugas untuk 
menyampaikan firman Tuhan saja, selebihnya Allah lah yang berdaulat dan Roh Kudus bekerja untuk membawa orang tersebut datang kepada Kristus.

Setiap orang yang sudah percaya menjadi saksi Tuhan di setiap keberadaannya. Oleh karena itu, orang percaya harus bertumbuh dalam kasih Karunia Allah dan firman-Nya dan menyerahkan hasil pemberitaan kepada Roh Kudus.(GP, 2012) . alah satu pekerjaan Roh Kudus yang dijelaskan oleh Brill(Brill, 2003) ialah menjelaskan penyataan-Nya, dalam artian memberikan kuasa untuk mengerti, mengetahui dan menerima pengajaran yang diajarkan. Dalam hal ini, Roh Kuduslah yang mengilhamkan Firman Allah dan Ia yang akan menegaskan kembali firman yang diajarkan, sehingga pendengar bisa memahami dan menjadi percaya akan Kristus Yesus.

Boice (Boice, 2011) menyatakan bahwa Roh Kudus mampu membuka mata-mata yang buta sehingga orang yang belum mengalami kelahiran baru dapat melihat kebenaran Allah, membuka pikiran sehingga dapat memahami apa yang dilihat. Dengan lembut Roh Kudus akan meyakinkan kehendak orang tersebut sampai datang untuk menempatkan iman pada Sang Juruslamat. Melalui hal ini, Roh Kudus menyelamatkan manusia dan memuliakan Tuhan Yesus. Orang yang dimenangkan oleh Roh Kudus akan membawa sukacita bagi dirinya sendiri dan menyenangkan hati Tuhan, karena umat-Nya telah diselamatkan.

\section{Kesimpulan}

Berdasarkan pemaparan di atas, maka dapat disimpulkan bahwa Roh Kudus sudah dicurahkan kepada orang percaya supaya dapat bersaksi. Kuasa Roh kudus diberikan kepada orang percaya supaya bekerja sama dengan-Nya bukan untuk mencapai tujuan manusia, tetapi untuk membawa orang-orang kepada Tuhan Yesus. Roh Kudus mengerjakan kelahiran baru sehingga orang dapat hidup dalam keselamatan dalam Yesus, mempersatukan orang percaya dalam keluarga Allah, dan memeteraikan orang yang percaya.

Ada tiga cara Roh Kudus membawa orang-orang kepada Kristus yaitu Allah menggunakan aktivitas Roh Kudus melalui firman-Nya, Allah menggunakan pelayanan Roh Kudus melalui kesaksian orang-orang percaya, dan Allah juga secara langsung menggunakan pekerjaan Roh Kudus dalam kehidupan orang-orang percaya supaya mereka bertobat dan menerima Kristus.

\section{Rujukan}

Andi, Y., Tola, O., Doma, Y., \& Suparta, I. K. G. (2020). Strategi Misi Lintas Budaya

Berdasarkan 1 Korintus 9:19-23. Jurnal Teologi Kontekstual Indonesia, 1(1), 57. https://doi.org/10.46445/jtki.v1i1.249

Boice, J. M. (2011). Dasar-Dasar Iman Kristen (Foundation of the Christian Faith).

Surabaya: Momentum.

Brill, W. J. (2003). Dasar Yang Teguh. Bandung: Kalam Hidup.

Darmawan, I. P. A. (2019). Jadikanlah Murid: Tugas Pemuridan Gereja Menurut Matius 
28:18-20. Evangelikal: Jurnal Teologi Injili Dan Pembinaan Warga Jemaat, 3(2), 144 153.

Darmawan, I. P. A., \& Asriningsari, A. (2018). Buku Ajar Penulisan Karya Ilmiah. Ungaran: Sekolah Tinggi Teologi Simpson.

Darmawan, I. P. A., \& Objantoro, E. (2020). Signifikansi Ineransi Alkitab Bagi Pendidikan Kristen. Sola Scriptura: Jurnal Teologi, 1(1), 36-52. https://doi.org/2722-855X

Dever, M. (2010). Sembilan Tanda Gereja Yang Sehat. Surabaya: Momentum.

Diana, R. (2019). Peran Komunikator Kristen Dalam Strategi Pekabaran Injil Di Era Revolusi Industri 4.0. Integritas: Jurnal Teologi, 1(1), 66-73.

Dixon, R. (2005). Tafsiran Kisah Para Rasul. Malang: Gandum Mas.

Enns, P. (2003). The Moody Handbook Of Theology Buku Pegangan Teologi. Malang: Literatur Saat.

Fernando, A. (2000). Allah Tritunggal dan Misi: Peran Bapa, Anak, Roh, dan Gereja dalam pekerjaan Misi alkitabiah. Jakarta: Yayasan Komunikasi Bina Kasih.

GP, H. (2012). Komunikasi Dalam Pemberitaan Injil: Membangun dan Mengembangkan Komunikasi Injil dalam Pelaksanaan Amanat Agung. Yogyakarta: Penerbit Andi.

Guthrie, D. (2007). 1 Korintus. In Tafsiran Alkitab Masa Kini 3: Matius-Wahyu. Jakarta: Yayasan Komunikasi Bina Kasih.

Harefa, F. L. (2020). Menggunakan Konsep Inkarnasi Yesus sebagai Model Penginjilan Multikultural. PASCA : Jurnal Teologi Dan Pendidikan Agama Kristen, 16(1), 50-61. https://doi.org/10.46494/psc.v16i1.75

Harming, H., Imanuel, G. Y., \& Darmanto, Y. (2020). Pelayanan Lintas Budaya: Sebuah Kajian Tentang Pelayanan Rasul Paulus Dalam Kisah Para Rasul 16:13-40. VOX DEI: Jurnal Teologi Dan Pastoral, 1(1), 78-89. https://doi.org/10.46408/vxd.v1i1.18

Harming, H., \& Katarina, K. (2019). Strategi Pelayanan Lintas Budaya Berdasarkan Markus 4:1-34. Evangelikal: Jurnal Teologi Injili Dan Pembinaan Warga Jemaat, 3(1), 113. https://doi.org/10.46445/ejti.v3i1.130

Henry, M. (2008). Injil Matius 15-28. Surabaya: Momentum.

Henry, M. (2015). Tafsiran Matthew Henry: Surat Roma, 1\&2 Korintus. Surabaya: Momentum.

Herwinasastra, H. (2019). Budaya Betangkant Anak Dalam Suku Dayak Keninjal Sebagai Upaya Kontektualisasi Kasih Allah. Evangelikal: Jurnal Teologi Injili Dan Pembinaan Warga Jemaat, 3(2), 200-207.

Huwae, E. (2020). Prinsip Dasar Pemberitaan Injil Menurut Kisah Para Rasul 28:23-31 . KAPATA: Jurnal Teologi Dan Pendidikan Kristen, 1(2), 119-136.

Ijen, I., \& Polyongkico, P. (2020). Analisis Pelayanan Filipus: Sebuah Konsep Teologi Kontekstual Berdasarkan Kisah Para Rasul 8: 4-25. Jurnal Teologi Kontekstual Indonesia, 1(2), 103-111.

Katarina, K., \& Darmawan, I. P. A. (2019). Alkitab dalam Formasi Rohani pada Era 
Reformasi Gereja dan Implikasi bagi Gereja Pada Masa Kini. EPIGRAPHE: Jurnal

Teologi Dan Pelayanan Kristiani. https://doi.org/10.33991/epigraphe.v3i2.85

Lumintang, S. I. (2006). Theologia \& Misiologia Reformed. Malang: YPPII.

Mawikere, M. C. S. (2018). Pendekatan Penginjilan Kontekstual Kepada Masyarakat Baliem

Papua. Jurnal Jaffray, 16(1), 25. https://doi.org/10.25278/jj71.v16i1.282

Miranda, J. (1986). Gereja Kristen Dalam Pelayanan. Malang: Gandum Mas.

Nikolaus, N., Andi, Y., \& Harming, H. (2020). Perumpamaan Penabur Benih Sebagai

Pendekatan Misi Lintas Budaya Berdasarkan Markus 4:1-20. Integritas: Jurnal Teologi,

2(1), 11-20. https://doi.org/10.47628/ijt.v2i1.18

Objantoro, E. (2017). Sejarah dan Pemikiran Kaum Injili di Tengah-tengah Perubahan dan

Tantangan Zaman. Evangelikal: Jurnal Teologi Injili Dan Pembinaan Warga Jemaat, 1(2), 129-138.

Rafflesia, M. (2019). Studi Eksegetis Peranan Roh Kudus Dalam Penginjilan Berdasarkan

Injil Yohanes 16:4B-15. 1(Oktober), 36-52.

Robinson, D. W. (2004). Total Church Life: Kehidupan Gereja yang Utuh. Bandung:

Literatur Baptis.

Servant, D. A. (2004). Pelayanan Pemuridan. Ungaran: Etnos Press.

Setiawan, D. E. (2019). Kelahiran Baru Di Dalam Kristus Sebagai Titik Awal Pendidikan

Karakter Unggul. Evangelikal: Jurnal Teologi Injili Dan Pembinaan Warga Jemaat, $3(2), 154-161$.

Siswanto, K. (2017). Perjumpaan Injil Dan Tradisi Jawa Timuran Dalam Pelayanan Misi

Kontekstual. Evangelikal: Jurnal Teologi Injili Dan Pembinaan Warga Jemaat, 1(1), 61-66.

Sitanggang, V. (2020). Penuh Roh Kudus Dalam Dimensi Keselamatan dan Misi. Sukabumi: CV Jejak (Jejak Publisher).

Smith, K. G. (2016). Writing and Research: A Guide for Theological Students. Cumbria: Langham Global Library.

Soesilo, Y. (2011). Pengalaman Pribadi Dengan Roh Kudus Sebagai Indikator Kualitas Pelayanan. Antusias: Jurnal Teologi Dan Pelayanan, 1(3), 109-117.

Sumiwi, A. R. E. (2018). Peran Roh Kudus Dalam Kehidupan Orang Percaya Masa Kini.

Jurnal Teologi Gracia Deo, 1(1), 23-31.

Swindoll, C. R. (2012). Ultimate Book of Illustrations \& Quotes. Bandung: Kalam Hidup. Tamarol, F. P. (2020). Tri Tunggal Tuhan Yang Maha Esa. Yogyakarta: PBMR Andi.

Tong, S. (1995). Roh Kudus, Doa dan Kebangungan. Surabaya: Lembaga Reformed Injili Indonesia.

Wagner, G. P. (2006). A Biblical Theology Of Missions. Malang: Gandum Mas.

Widjaja, F. I., \& Boiliu, N. I. (2019). Misi dan Pluralitas Keyakinan di Indonesia.

Yogyakarta: Penerbit Andi. https://doi.org/10.31219/osf.io/wrnmy

Wijaya, P. A., \& Darmawan, I. P. A. (2016). Pembekalan Pendekatan Penginjilan di GKII 
Gerizim Nusa Dua. Prosiding Seminar Nasional Pendidikan Agama Kristen STT Simpson Tahun 2016 Tema: Strategi Pembinaan Jemaat Untuk Meningkatkan

Kehidupan Jemaat, 52-57. Ungaran: Sekolah Tinggi Teologi Simpson. Retrieved from http://semnas.sttsimpson.ac.id/index.php/SNPK/article/view/7

Zaluchu, S. E. (2020). Strategi Penelitian Kualitatif dan Kuantitatif Di Dalam Penelitian Agama. Evangelikal: Jurnal Teologi Injili Dan Pembinaan Warga Jemaat, 4(1), 28-38. https://doi.org/https://doi.org/10.46445/ejti.v4i1.167

Zaluchu, S. E. (2021). Metode Penelitian di dalam Manuskrip Jurnal Ilmiah Keagamaan. Jurnal Teologi Berita Hidup, 3(2), 249-266. https://doi.org/10.38189/jtbh.v3i2.93 